\title{
Climate variables along a traverse line in Dronning Maud Land, East Antarctica
}

\author{
Mighiel R. van den Broeke, ${ }^{1 *}$ Jan-Gunnar Winther, ${ }^{1}$ Elisabeth Isaksson, ${ }^{1}$ \\ Jean Francis Pinglot, ${ }^{2}$ Lars Karlöf, ${ }^{3}$ Trond Eiken, ${ }^{1}$ Louk Conrads ${ }^{4}$ \\ ${ }^{1}$ Norwegian Polar Institute, P.O. Box 399, N-9005 Tromso, Norway \\ ${ }^{2}$ Laboratoire de Glaciologie et Géophysique de l'Environnement du CNRS, BP 96, 38402 Saint-Martin-d'Hères Cedex, France \\ ${ }^{3}$ Department of Physical Geography, Stockholm University, S-106 91 Stockholm, Sweden \\ ${ }^{4}$ Institute for Marine and Atmospheric Research, Utrecht University, P.O. Box 80005, 3508 TA Utrecht, The Netherlands
}

\begin{abstract}
ABSTRAGT. Temperature, density and accumulation data were obtained from shallow firn cores, drillcd during an overland traverse through a previously unknown part of Dronning Maud Land, East Antarctica. The traverse area is characterised by high mountains that obstruct the ice flow, resulting in a sudden transition from the polar plateau to the coastal region. The spatial variations of potential temperature, ncar-surface firn density and accumulation suggest that katabatic winds are active in this region. Proxy wind data derived from firn-density profiles confirm that annual mean wind speed is strongly related to the magnitude of the surface slope. The high elevation of the ice sheet south of the mountains makes for a dry, cold climate, in which mass loss owing to sublimation is small and erosion of snow by the wind has a potentially large impact on the surface mass balance. A simple katabatic-wind model is used to explain the variations of accumulation along the traverse line in terms of divergence/convergence of the local transport of drifting snow. The resulting wind- and snowdrift patterns are closely connected to the topography of the ice shect: ridges are especially sensitive to crosion, while ice strcams and other depressions act as collectors of drifting snow.
\end{abstract}

\section{INTRODUCTION}

Within the Europcan Project for Icc Coring in Antarctica (EPICA) it is planned to obtain two deep ice cores from the Antarctic ice sheet. The first one is at present being drilled at Dome C, and will hopefully provide scientists with one of the longest undisturbed climate archives to date. The second core site should be characterised by higher accumulation rates with a dominant contribution of prccipitation from the South Atlantic Ocean (the "Atlantic signal") to make the link with climate data obtaincd from cores retrieved on the Greenland ice sheet. Although it has been decided that this core will be drilled somewhere in Dronning Maud Land (DML), its exact position is yet to be determined. To this end, a reconnaissance phase has been planned that consists of several pre-sitc surveys. This paper presents some results of the Norwegian/Swedish/Dutch ground traverse that was held during the 1996-97 field season as part of the EPICA programme. The traverse, supported by the Norwegian Antarctic Research Expedition, started out from the edge of the Fimbulisen ice shelf and ended at $75^{\circ} \mathrm{S}, 15^{\circ} \mathrm{E}$ (3453 $\mathrm{m}$ a.s.1.), via the Norwegian station Troll (1298 $\mathrm{m}$ a.s.l.) (Fig. 1). The end-point is situated approximately halfway along the ridge connccting Troll and

* Present address: Institute for Marine and Atmospheric Research, Utrecht University, P.O. Box 80005, 3508 TA Utrecht, The Netherlands.
Valkyrjedomen, the highest point of DML ( $3810 \mathrm{~m}$ a.s.l.), on which the Japanese station Dome $\mathbf{F}$ is situated.

From a glaciological and meteorological point of view, the part of DML between $0^{\circ}$ and $15^{\circ} \mathrm{E}$ and $70^{\circ}$ and $75^{\circ} \mathrm{S}$ is practically unknown; most glaciological data are available from arcas further north, south and cast. The South PoleQueen Maud Land Traverse (1964-68) covered large areas between the South Pole and $76^{\circ} \mathrm{S}, 7^{\circ} \mathrm{E}$ (Picciotto and Crozaz, 1971). East of $15^{\circ} \mathrm{E}$, Japanese expeditions have collected glaciological data since the launch of the Enderby Land Glaciological Observation Programme in 1969, which rccently resulted in the publication of a glaciological folio covering the area $15-55^{\circ} \mathrm{E}$, from the coast to $80^{\circ} \mathrm{S}$ (NIPR, 1997). To the north and west of Troll, data are available from two early expeditions that operated from the Maudheim and Norway stations (Schytt, 1958; Lunde, 1961). To the south and west, recent German and Swedish traverses obtained data from shallow and medium-deep ice cores as well as snow radar (Isaksson and others, 1996; Richardson and others, 1997).

For a more detailed description of the traverse and methods used, the reader is referred to Winther and others (1997). Results of chemical analysis of snow pits and firn cores, as wcll as detailed accumulation records obtained with snow radar, will be presented in forthcoming papers.

\section{RESULTS}

Table 1 lists the location, elevation, $10 \mathrm{~m}$ temperature and accumulation rate at the 15 locations at which shallow 9 


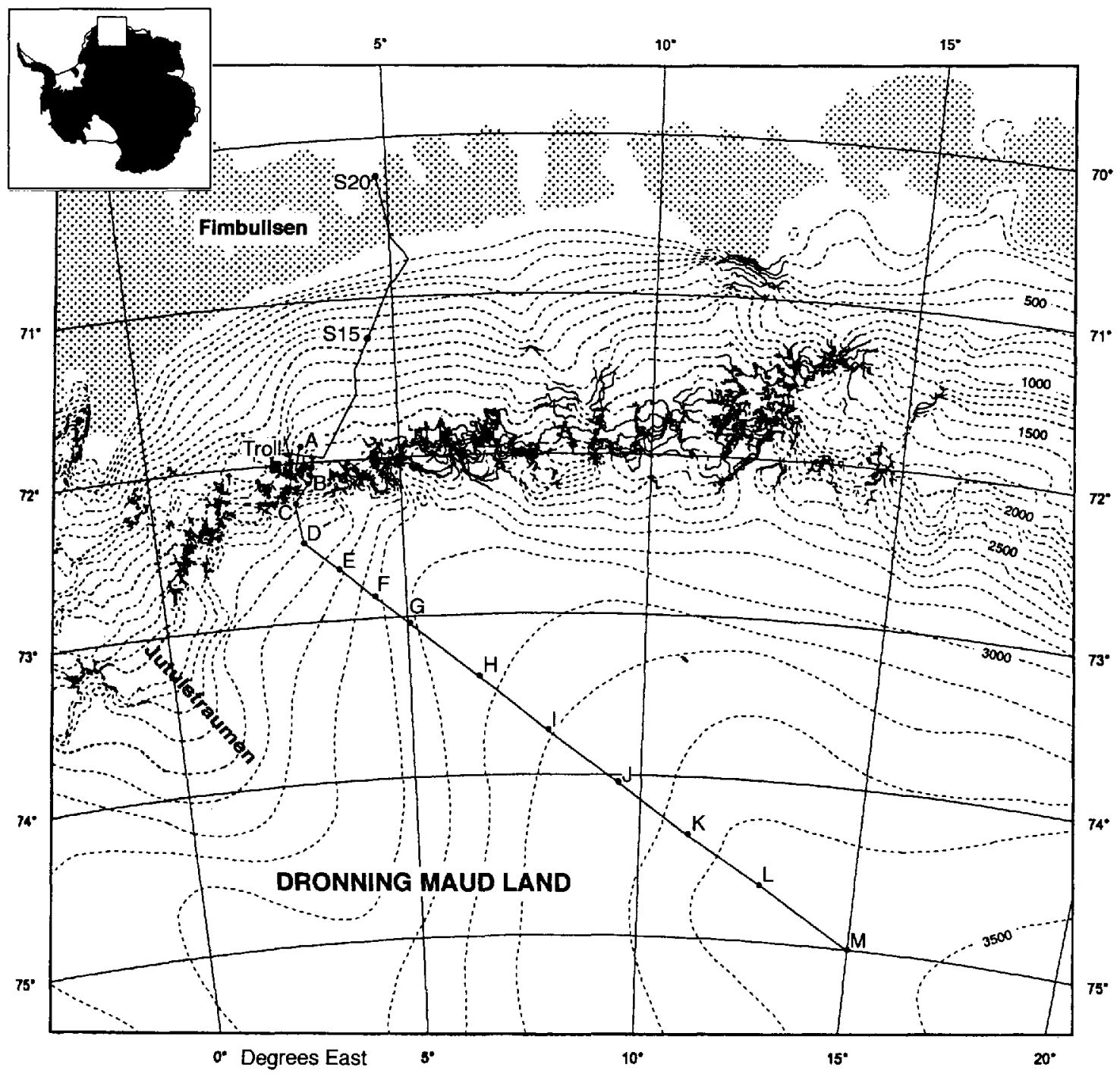

Fig. 1. Traverse area in DML. Solid line showes traverse route with sites and names where shallow firn cores were drilled (Table 1). Elevation data are from the Antarctic Digital Database.

$20 \mathrm{~m}$ ) firn cores were drilled; site names correspond to those prescnted in Figure 1. In the following, some results are discussed in more detail.

\subsection{Elevation and slope}

The morphology of DML differs substantially from other areas in East Antarctica: between $15^{\circ} \mathrm{W}$ and $30^{\circ} \mathrm{E}$, high mountains obstruct the ice flow at many places, which rcsults in an abrupt transition from the polar plateau $(>2500 \mathrm{~m}$ a.s.l.) to the coastal zone $(<1500 \mathrm{~m}$ a.s.l.). Betwecn the mountains, decp drainage basins are present that are visible as depressions in the surface of the ice sheet for hundreds of $\mathrm{km}$ upstream. The largest ice stream in this part of DML is Jutulstraumen which drains an area of approximately $124000 \mathrm{~km}^{2}$ (Fig. 1).

Figure 2 shows surface elevation and slope along the traverse line; the distance to the coast was calculated assuming the coastline to be at $70^{\circ} \mathrm{S}$. The large-scale terrain slope (based on $5 \mathrm{~km}$ mean elevation) shows several maxima; the broadest peak represents the transition from the polar plateau to the coastal zone via the glacier Slithallet, and several narrower pcaks identify the transition from the land-based ice shect to the Fimbulisen ice shelf (Fig. 2). Bascd on the elevation profile, three zones can be defined, as indicated in Figure 2: ice shelf, coastal zone and plateau.

\subsection{Temperature at $10 \mathrm{~m}$ depth}

'len-metre temperatures at drill sites are listed in Table 1 and Figure 3. At $10 \mathrm{~m}$ depth, the amplitude of the annual temperature wave at the snow surface is reduced to approximately $5 \%$ of its surface valuc, i.e. typically $0.75^{\circ} \mathrm{C}$ for coastal stations and $1.75^{\circ} \mathrm{C}$ on the plateau. The $10 \mathrm{~m}$ temperature is therefore a reasonable measure of the annual mean surface tcmperaturc. Deviations from the real annual mean surface temperature arise from various (non-instrumental) sources: during summer, when most measurements are performed, the cold wave from the previous winter is just passing the $10 \mathrm{~m}$ depth level (Schlatter, 1972; Bintanja and others, 1997), leading to a systematic underestimation of the annual mean value. Another problem is the long period needed for the thermistor string to reach thermal equilibrium with its surroundings, typically $15 \mathrm{~h}$ (Seppälä, 1992). This caused problems at sites $E$ and $G$, where only short stops were made and values had to be adjusted downward by $1.1 \mathrm{~K}$ to achicve better agreement with neighbouring values (Fig. 3). At sites $H, K$ and $L$, the boreholes were slightly less than $10 \mathrm{~m}$ deep (Table 1). At these sites, temperatures were measured at the lowest possible level. The uncertainties describcd above culminate in an estimated uncertainty of $\pm 1^{\circ} \mathrm{C}$. Note that recalibration of the thermistor string after the expedition for tempcratures down to 
Table 1. Position, surface elevation, $10 \mathrm{~m}$ temperature and accumulation at drilling sites along the traverse (forlocations, see Fig. 1)

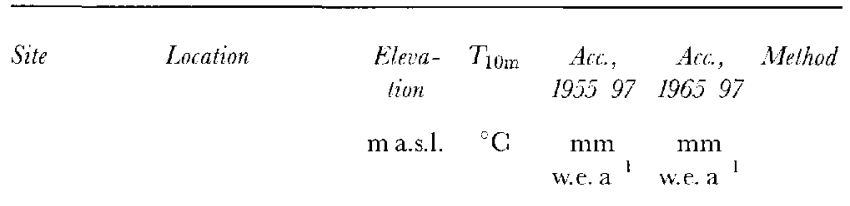

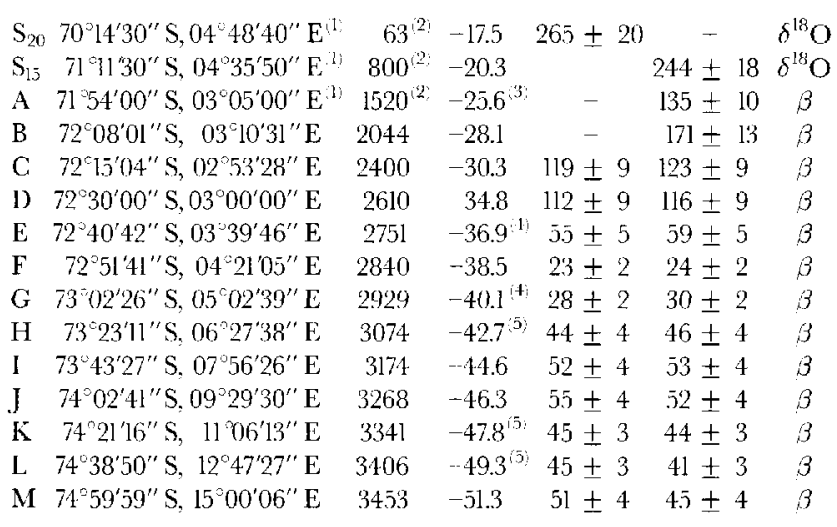

Kote: All positions are from ovcrnight precision global positioning system (GPS) measurements unless otherwise noted.

1. Horizontal position from hand-held GPS receivers

Elevation from tracked vehicle GPS record.

(3) From AWS thermistor strings.

t. Corrected for non-stationarity:- - $1.1 \mathrm{~K}$

(5) Measured at 9.8,9.9 and $9.0 \mathrm{~m}$ depth at sites $\mathrm{H}, \mathrm{K}$ and $\mathrm{L}$, respectively.

$60^{\circ} \mathrm{C}$ resulted in an upward adjustment of $0.8-2.9^{\circ} \mathrm{C}$ compared to the preliminary temperatures listed in Winther and others (1997).

The temperature of $-17.5^{\circ} \mathrm{C}$ at the coastal site $\mathrm{S}_{20}$ compares well with values obtained further west on the Fimbulisen ice shelf at Norway station $\left(-18.2^{\circ} \mathrm{C}\right.$; Lunde, 1961 ), Maudheim $\left(-17.4^{\circ} \mathrm{C}\right.$; Schytt, 1958) and SANAE III $\left(-18.4^{\circ} \mathrm{G}\right)$; further east, annual mean temperatures at or close to sea level are significantly higher, for example at Novolazcrevskaya $\left(-10.4^{\circ} \mathrm{C}\right)$, Syowa $\left(-10.5^{\circ} \mathrm{C}\right)$ and Molodezhnaya $\left(-11.0^{\circ} \mathrm{C}\right)$. The colder climate further west can be ascribed to

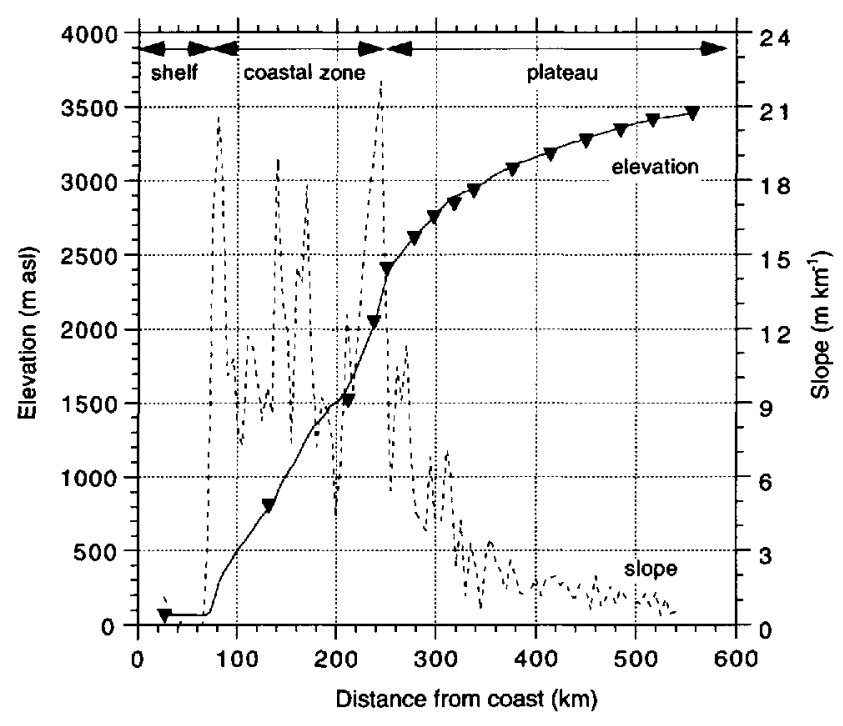

Fig. 2. Surface elevation (solid line) and terrain slope (dashed line). For the calculation of distance to the coast ( $x$ axis, the coastline is assumed to be $70^{\circ} \mathrm{S}$. Drilling locations are indicated by triangles.

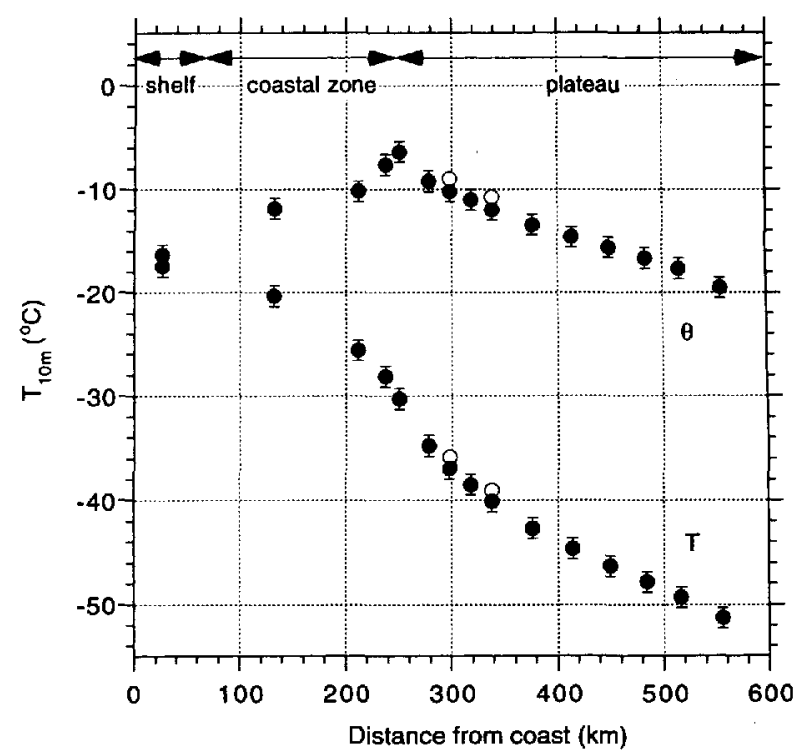

Fig. 3. Absolute and polential temperature at $10 \mathrm{~m}$ depth in the firn. White dots indicate uncorrected temperatures al siles $E$ and $G$. Error bars indicate \pm 1 standard error.

the presence of the extended Fimbulisen ice shelf, where strong temperature inversions develop at the surface, in contrast to places that are subject to katabatic winds from the inland ice.

The $10 \mathrm{~m}$ firn temperature shows a continuous decline further inland (Fig. 3), as would be expected given the increasing clcvation of the icc shect and greater distance from the ocean. A better variable to study is the potential temperature, defined as the temperature an air parcel would have if it were brought to sea level without heat exchange with its surroundings:

$$
\theta=T_{\mathrm{v}}\left(\frac{p_{0}}{p}\right)^{R_{\mathrm{d}} / C_{\mathrm{p}}}
$$

where $T_{\mathrm{v}}=T(1+0.61 q)$ is the virtual temperature, $q$ is the specific humidity ( $\mathrm{kg}$ moisture per $\mathrm{kg}$ air), $p_{0}=1000 \mathrm{hPa}$ is the reference pressure, $R_{\mathrm{q}}=287 \mathrm{~J} \mathrm{~kg}{ }^{\mathrm{l}} \mathrm{K}^{1}$ is the dry gas constant of the atmosphere and $C_{\mathrm{p}}=1005 . \mathrm{J} \mathrm{kg}^{-1} \mathrm{~K}^{-1}$ is the specific heat at constant pressure. Because we do not have information on the local air pressure, we use an empirical relation that expresses annual mean air pressure as a function of clevation $h_{s}$, based on data of 21 Antarctic stations (Schwerdtfeger, 1970: $\ln p=11.504-0.00013324 h_{\mathrm{s}}$ ). Because the humidity content of Antarctic air is very low $(0.1-0.5 \mathrm{~g}$ $\mathrm{kg}^{-1}$ in winter, $0.1-3 \mathrm{~g} \mathrm{~kg}^{1}$ in summer), we can assume $T \approx T_{\mathrm{v}}$ within $0.1-0.3^{\circ} \mathrm{C}$. The potential temperature thus obtained is included in Figure 3. If surface-temperature changes with elcvation were to be dry adiabatic (no mixing, no phase changes), potential temperature would be constant along the traverse linc. Clearly, this is not the case, with a maximum in $\theta$ at site $\mathrm{C}$, at the edge of the plateau. This is a signature of enhanced mixing, which will be further discussed in section 3 .

\subsection{Firn density}

The vertical density profile of the uppermost $10-20 \mathrm{~m}$ of polar firn is usually described as a function of overburden pressure and local physical quantities like annual mean temperature, wind speed and accumulation. Higher tempcratures enhance grain growth, increasing the densifica- 
tion rate, while mechanical rounding of snow particles by wind action facilitates settling and enhances density in the upper metres. The latter effect is dampened by high accumulation. Extending work of Kameda and others (1994), Craven and Allison (1998) presented the following implicit equation describing the density profile of dry polar firn:

$$
\ln P=c_{1} S^{2}+c_{2} T_{10 \mathrm{~m}}+c_{3} V+c_{4} \mathrm{Acc}+c_{\overline{5}},
$$

where the overburden pressure $P$ is the depth-integrated wcight of the overlying snow, $S=\left(\rho_{\mathrm{i}}-\rho\right) / \rho_{\mathrm{i}}$ is the porosity, with $\rho_{\mathrm{i}}$ the density of bubble-free pure ice (taken as $917 \mathrm{~kg} \mathrm{~m}^{3}$ ), $T_{10 \mathrm{~m}}$ is $10 \mathrm{~m}$ temperature, $V$ is annual mean wind speed and Acc is annual accumulation. Values of the coefficients $c_{1}$ to $c_{5}$ were obtained by Graven and Allison through multiple regressions, using data from ten stations where density profiles and climate data were available. Kameda and others (1994) included only temperature, setting $c_{3}$ and $c_{4}$ to zero.

Figure 4 a shows the average density of depth intervals $0-1$ and $0-10 \mathrm{~m}$ of the firn along the traverse line as a function of distance to the coast. On the ice shelf, densities are
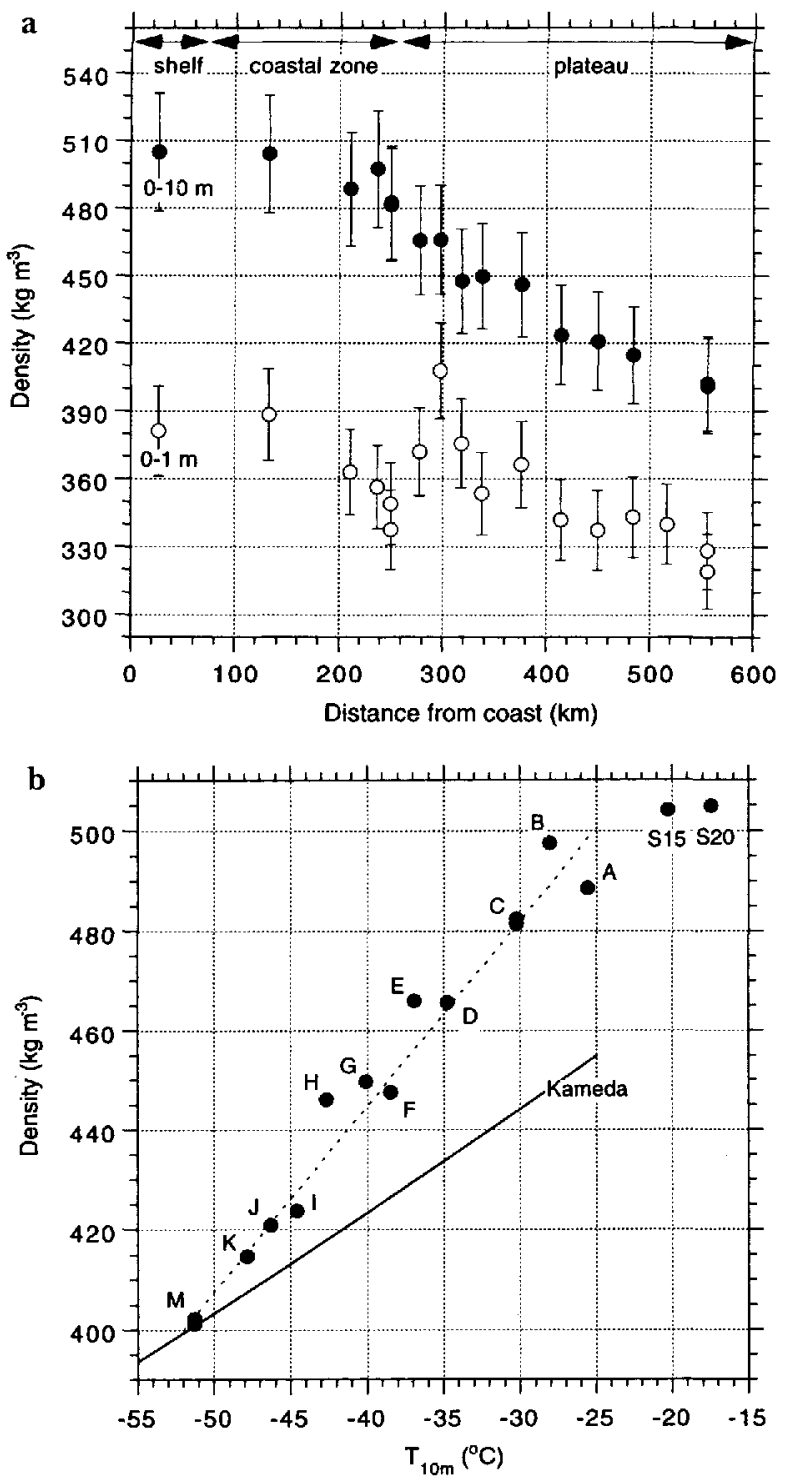

Fig. 4. (a) Average firn density for the depth intervals $0-1 \mathrm{~m}$ (white dots) and $0-10 \mathrm{~m}$ (black dots). Error bars indicate \pm 1 siandard error. (b) Average firn density $(0-10 \mathrm{~m})$ as function of $10 \mathrm{~m}$ temperature. Solid line indicates values calculated using the expression of Kameda and others (1994). Error bars indicate \pm 1 standard error. high and the abundance of ice lenses indicates that surface melting occurs during summer, which is confirmed by observations somewhat further west (Winther and others, 1997). Further inland, the $0-10 \mathrm{~m}$ average density decreases in a uniform fashion in response to lower temperatures. The 0-1 $\mathrm{m}$ average density has a clear maximum at site $\mathrm{E}$, probably caused by the combined work of low accumulation and strong winds. We compared our results to values obtained with the formula of Kameda and others (1994) (Fig. 4b). The most striking feature is the linear dependence of 0 $10 \mathrm{~m}$ average density on temperature for $T_{10 \mathrm{~m}}<-25^{\circ} \mathrm{C}$, with density increasing at a rate of $3.3 \mathrm{~kg} \mathrm{~m}^{-3} \mathrm{~K}^{-1}$. This increase is twice as large as the increase predicted by the formula of Kameda and others (1994). According to Craven and Allison (1998), this can be ascribed to the action of strong (katabatic) winds. This will be further discussed in section 3.

\subsection{Accumulation}

To obtain local accumulation rates, the depths of the reference levels of March 1955 and January 1965 (Pourchct and others, 1983) were located by total $\beta$ radioactivity measurements of snow samples (Pinglot and Pourchet, 1979). For cores $S_{20}$ and $S_{15}$, seasonal variations of oxygen isotopes $\left(\delta^{18} \mathrm{O}\right)$ were used for dating. Following the approach of Venteris and Whillans (1998), the local accumulation rate (in

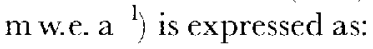

$$
\text { Acc }=\frac{4}{\pi t} \sum_{i} \frac{M_{i}}{d_{i}^{2}}
$$

where $t$ is the time-span between core retrieval and the dated stratum (in years), and $M_{i}$ is the mass and $d_{i}$ the diamcter of core section $i$ above the dated horizon. The standard error in the accumulation $\sigma_{\text {Acc }}$ due to measurement uncertainties equals the sum of the first terms in a Taylor series of the local derivatives in Equation (3a):

$$
\left(\frac{\sigma_{\mathrm{Acc}}}{\mathrm{Acc}}\right)^{2}=\left(\frac{2 \sigma_{\mathrm{d}}}{\bar{d}}\right)^{2}+\left(\frac{\sigma_{\mathrm{t}}}{t}\right)^{2}+\left(\frac{\sigma_{\mathrm{M}}}{\bar{M}}\right)^{2}
$$

where $\sigma_{\mathrm{d}}$ and $\sigma_{\mathrm{M}}$ are the uncertainty in diameter $(2 \mathrm{~mm})$ and mass $(3 \mathrm{~g})$, respectively. The bar indicates average valucs for the corc picces above the dated stratum. The uncertainty in the time-span $\sigma_{\mathrm{t}}$ arises from the dimension of the core piece to which the $\beta$ surge was assigned (typically $10-20 \mathrm{~cm}$ ). In low-accumulation areas $\sigma_{\mathrm{l}} / t$ is typically comparable in magnitude to $2 \sigma_{d} / \bar{d}$, both of the order of $5 \%$, but usually the uncertainty in diameter dominates. The contribution to the total error of $\sigma_{M} / \bar{M}$ is small, typically $<1 \%$.

The resulting accumulation figures are presented in Table 1 and Figure 5. Accumulation on the high plateau (>400 km from the coast) for the period 1965.97 appears to have been somcwhat lower than for $1955-97$, while the opposite is true of plateau sites closer to the coast, but the differences are not statistically significant. Lpon closer inspection Isaksson and others (1999) found statistically significant differences between the periods 1955-65 and 196597 , which agrees with earlicr measurements in this part of Antarctica (Isaksson and others, in press) and could be due to a recent weakening of meridional exchange of air masses since the 1970 s (Van den Broeke, 1998a, b). In the coastal area and on the ice shelf, accumulation increases to 240 $270 \mathrm{~mm}$ w.e. The accumulation at site $S_{20}$ is lower than the value for Maudheim, some $600 \mathrm{~km}$ to the west $(365 \mathrm{~mm}$ w.e; 


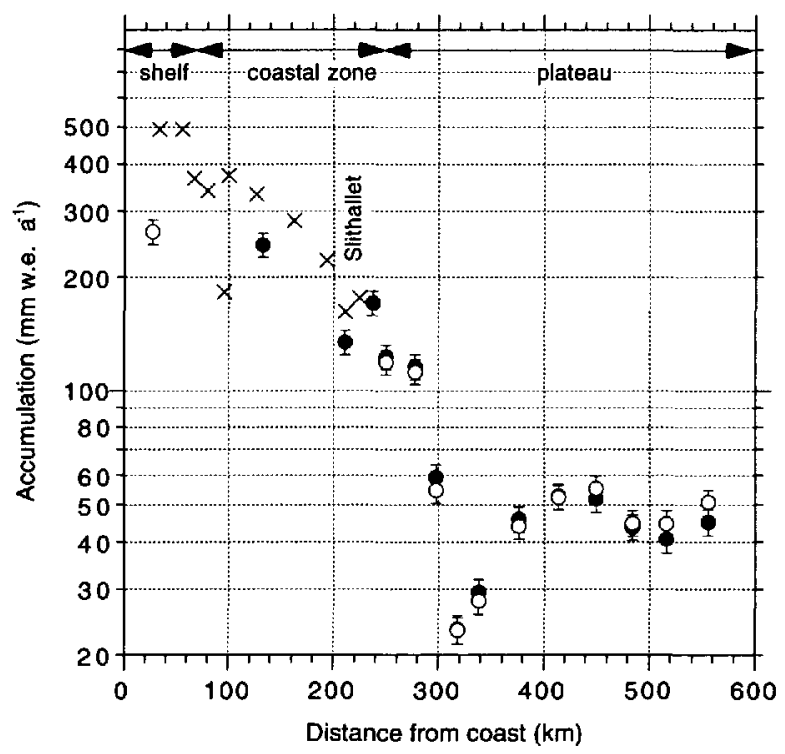

Fig. 5. Annual accumulation along the traverse line, 1955-97 (white dots) and 1965-97 (black dots). Crosses represent accumulation values between. Norway station and Troll and onto the glacier Slithallet (Lunde, 1961). Error bars indicate \pm 1 standard error.

Schytt, 1958), and Norway station, some $300 \mathrm{~km}$ to the west (495 mmw.e. for the period 1940-59 (Lunde, 1961), and $480 \mathrm{~mm}$ w.e. for the period 195594 (personal communication from K. Mclvold, 1998)). The crosscs in Figure 5 represent stake measurements during the International Geophysical Year (1957-58) and the following years, that were performed between Norway station and Troll (Lunde, 1961).

On the plateau, ycarly accumulation rates vary between 40 and $60 \mathrm{~mm}$ w.e., but $300-400 \mathrm{~km}$ from the coast the accumulation has a significant local minimum $(24 \mathrm{~mm}$ w.e. at site $F$ ). In agreement with the low accumulation are the ${ }^{137} \mathrm{Cc}$ deposition rates at sites $\mathrm{F}$ and $\mathrm{G}\left(32\right.$ and $\left.38 \mathrm{~Bq} \mathrm{~m}^{-2}\right)$, which are about half the value of the adjacent sitcs $(65 \mathrm{~Bq}$ $\left.\mathrm{m}^{-2}\right)$. At these locations, extensive hoar layers have developed in the snowpack. The most likely reason for the low accumulation is the combined work of low precipitation and divergence of snowdrift transport, a topic that will be discussed in the next section. A similar dry area with annual accumulation of $<50 \mathrm{~mm}$ w.e. has been observed further east (NIPR, 1997), so this featurc is likely to be represcntative of large parts of DMI and possibly other parts of Antarctica (Pettré and others, 1986). Other, less significant, minima in the accumulation profile are found at the foot of Slithallet (the glacier that connects sites A and B) and $500 \mathrm{~km}$ from the coast (sites $\mathrm{K}$ and L).

\section{DISGUSSION}

\subsection{Temperature, wind speed and density}

Antarctica reflects most of the solar radiation back to space, resulting in a negative radiation balance at the surface (except during the summer months). As a result, a quasi-permanent surface-temperature inversion is present which varies in intensity from $1-2^{\circ} \mathrm{C}$ at coastal stations at the foot of the ice cap (Streten, 1990) to about $10^{\circ} \mathrm{C}$ on the ice shelves (King and Turner, 1997) and $20-25^{\circ} \mathrm{C}$ on the polar plateau (Phillpot and Zillman, 1970). Over sloping terrain, the cold, dense air is forced downward by gravity and deflected to the left by the Coriolis force, resulting in "inversion" or "katabatic" winds.

$\Lambda$ proxy annual mean wind speed can be obtained by fitting the observed density profiles to empirical firn profiles (Equation (2), and minimising the sum of the squared residuals. We chose $2-10 \mathrm{~m}$ as fitting interval, in order to obtain comparable results for all sites. 'Lo illustrate this procedure, Figure 6 shows theoretical and observed density profiles for a $12 \mathrm{~m}$ corc at site $C_{i}$, for various values of the prescribed wind speed. Apart from the uncertainty in the coefficients in Equation (2), the error in the annual mean wind speed thus obtaincd arises mainly from uncertainties

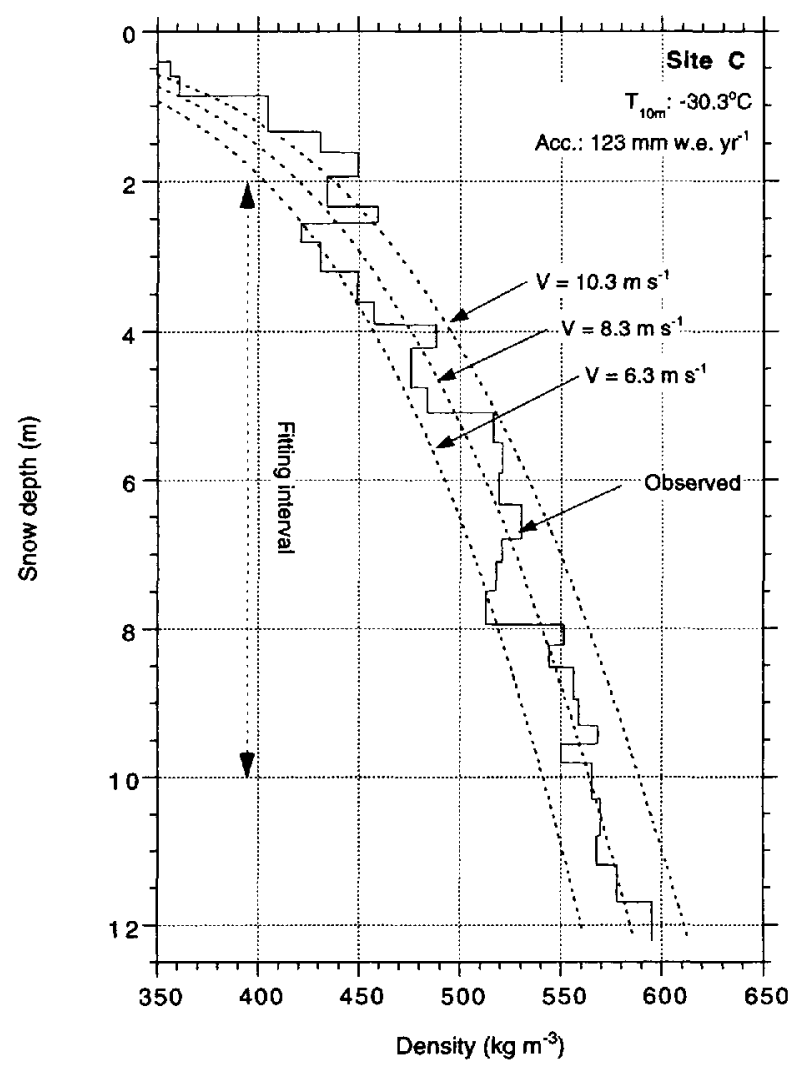

Fig. 6. Example of fitting theoretical firn profiles (Craven and Allison, 1998) to observalions, in order to oblain a proxy annual mean wind speed. Fitting procedure is based on minimising the squared residuals at $10 \mathrm{~cm}$ intervals between 2 and $10 \mathrm{~m}$ depth for various wind speeds (wind-speed interval: $0.1 \mathrm{~ms}^{-1}$ ).

in obscrved density (i.e. core diameter): crror propagation yields a $20 \%$ uncertainty in annual mean wind specd. Results of this procedure are presented in Figure 7 . The method was not used for the sites to the north of site A, because Equation (2) is known to yield poor results in highaccumulation arcas (Craven and Allison, 1998). Instead, annual mean wind speeds at Norway station and Maudheim have been plotted as representative wind speeds on Fimbulisen. As a typical value for the high platcau in DML, the annual mean wind speed at Dome $F$ has also been included. One year of wind-specd data is available from automatic weather stations ( $\Lambda \mathrm{WSs}$ ) at sites $\mathrm{A}$ and $\mathrm{C}$; these observations confirm the density-derived wind speeds.

The proxy wind-speed profile in Figure 7 shows a rapid increase in the area where surface slope increases, which is typical for gravity-driven winds. In the coastal area, radia- 


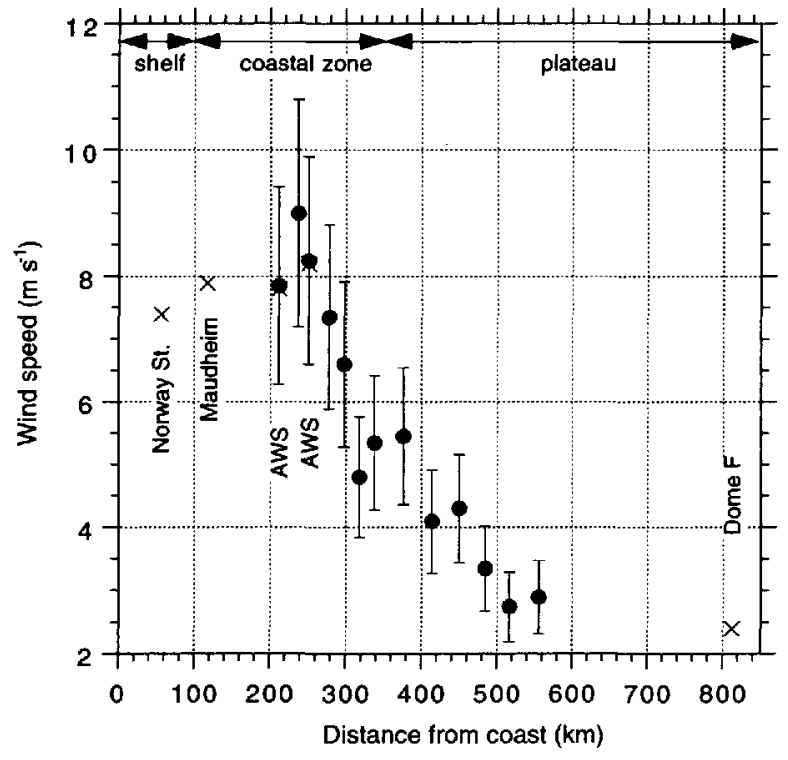

Fig. 7. Proxy annual mean wind speed, derived from firn-density profiles ( see text for more details). Crosses represent observations. Error bars indicate \pm 1 standard error.

tional cooling is less pronounced and the katabatic component is smaller. In the absencc of a significant katabatic component on the flat ice shelves, the annual mean wind speed is determined by the large-scale prcssure gradient.

Under strong wind conditions, the temperature inversion near the surface will be (partly) destroyed by enhanced vertical mixing, because the latter process warms the surface through the incrcased downward turbulent transport of sensible heat; these warm signatures are detectable on infrared satellite imagery, and are often interpreted as areas where katabatic winds are active (Bromwich, 1989). Another factor that modifies near-surface air temperatures is entrainment of warm air at the top of the atmospheric boundary layer (ABL) and subscquent downward mixing. Entrainment is most vigorous when the ABL wind speeds are high compared to the frec atmosphere (i.e. large wind shear at the ABL top). For both these processes, surface temperature increases at higher wind speeds.

Following the line of reasoning above, the maximum value of the surface potential temperature along the traverse line in Figure 3 is indicative of a katabatic-wind climate, with weak winds in the interior, stronger winds at the edge of the plateau where the surface slope increases and again weaker winds on the ice shelves. This qualitatively confirms the wind-speed profile presented in Figure 7.

\subsection{Accumulation}

In general, accumulation as measured at an $\Lambda$ ntarctic snow surface is the sum of precipitation, sublimation/deposition of water vapour, erosion/deposition/sublimation through snowdrift and melting. Fxcept in the coastal zone, melting is assumed to be small. Bintanja and Van den Brocke (1995), Bintanja and others (1997) and Van den Broeke (1997) showed that sublimation can be an important term in the mass balance of lower-lying areas in Antarctica $<2000 \mathrm{~m}$ a.s.l.), where relatively high surface temperatures allow for significant water-vapour pressures at the snow surface. However, annual sublimation at site F ( $2840 \mathrm{~m}$ a.s.l.) is unlikely, at such a high elevation, to excced $10 \mathrm{~mm}$ w.e. a ${ }^{1}$. Sub- limation is therefore insufficient to explain the observed minimum in accumulation in Figure 5.

Another process that could account for the accumulation variations along the traverse line is erosion/deposition arising from the divergence/convergence of snowdrift transport, that can be expressed as

$$
\text { Erosion }=\frac{\partial Q}{\partial x}+\frac{\partial Q}{\partial y}
$$

where $Q$ is the local snowdrift transport $\left(\mathrm{kg} \mathrm{m}^{-1} \mathrm{a}^{-1}\right)$, and $x, y$ are aligned in the down- and cross-slope directions, rcspectively. Unfortunately, from our one-dimensional proxy wind-speed profile in Figure 7 it is not possible to estimate the cross-slope divergence $\partial Q / \partial y$, nor can we incorporate the influence of a changing wind direction along the slope. Wind direction is known to show important variations in response to a changing ratio between katabatic, Coriolis and friction forces (Van den Broeke and Bintanja, 1995b; Van den Broeke and others, 1997). From the continuous increase of wind speed on the plateau (Fig. 7) it is clear that $\partial Q / \partial x$ alone cannot account for a maximum in erosion at site $\mathrm{F}$, and cross-slope divergence is likely to play an important role.

To account in a more complete way for the effect of spatial variations in the wind field on the distribution by snowdrift transport, we used a theoretical katabatic-wind model developed by Ball (1960) to calculate wind speed and wind direction, analogous to the approach of Takahashi and others (1988) and Van den Broeke and Bintanja (1995a). In addition to the downslope pressurc gradient, we prescribed a climatic synoptic pressure gradient that forces easterly winds of $6 \mathrm{~m} \mathrm{~s}^{-1}$ at the coast and that decreases as a linear function of elevation. Furthermore, instead of an cxpression for the temperature inversion as a function of altitude, we calculated the inversion strength using a power relation between our proxy mean wind speed and three variables: clevation, distance from the coast and surface slope. The local annual transport of snow by the wind $Q$ was then cstimated from the annual mean wind speed $V$, using a relation based on drift data of Locwe (1970) and annual mean wind speed at 18 Antarctic stations, and erosion/deposition calculatcd with Equation (4) on a $10 \mathrm{~km} \times 10 \mathrm{~km}$ grid.

The resulting climatic near-surface wind ficld is presented in Figure 8a. The wind field shows two main characteristics. First, there is a distinct meridional variation, with low wind speeds on the high plateau, an increase over the steeper slopes of the ice-sheet topography and a decrease over the ice shelves. This results in an approximatcly $50 \mathrm{~km}$ wide band where significant erosion is predicted $(>5 \mathrm{~mm}$ w.e. $\mathrm{a}^{-1}$; Fig. 8 b), at $2000-3000 \mathrm{~m}$ a.s.l. Significant deposition (>50 mm w.e. $\mathrm{a}^{-1}$ ) occurs in the coastal zone and on the icc shelves where the katabatic wind ceases. Note that the synoptic pressure gradient enhances the east-west directed component of the katabatic wind. Superimposed on this pattern, zonal variations can be detceted where the wind field diverges over ridges and promontories in the topography and converges in depressions and glacier basins.

The pattern of erosion/deposition as calculated from this simple model is presented in Figure $8 \mathrm{~b}$. Along the traverse line, the model predicts significant erosion in three regions: 5-25 $\mathrm{mm}$ w.e. between sites $\mathrm{K}$ and $\mathrm{L}, 5-50 \mathrm{~mm}$ w.e. in the region of sites $\mathbf{E}-\mathrm{G}$, and $25-100 \mathrm{~mm}$ w.e. at the transition between plateau and coastal zone (sites $\mathrm{C}$ and $\mathrm{D}$ ). These values correspond well to the local accumulation minima 

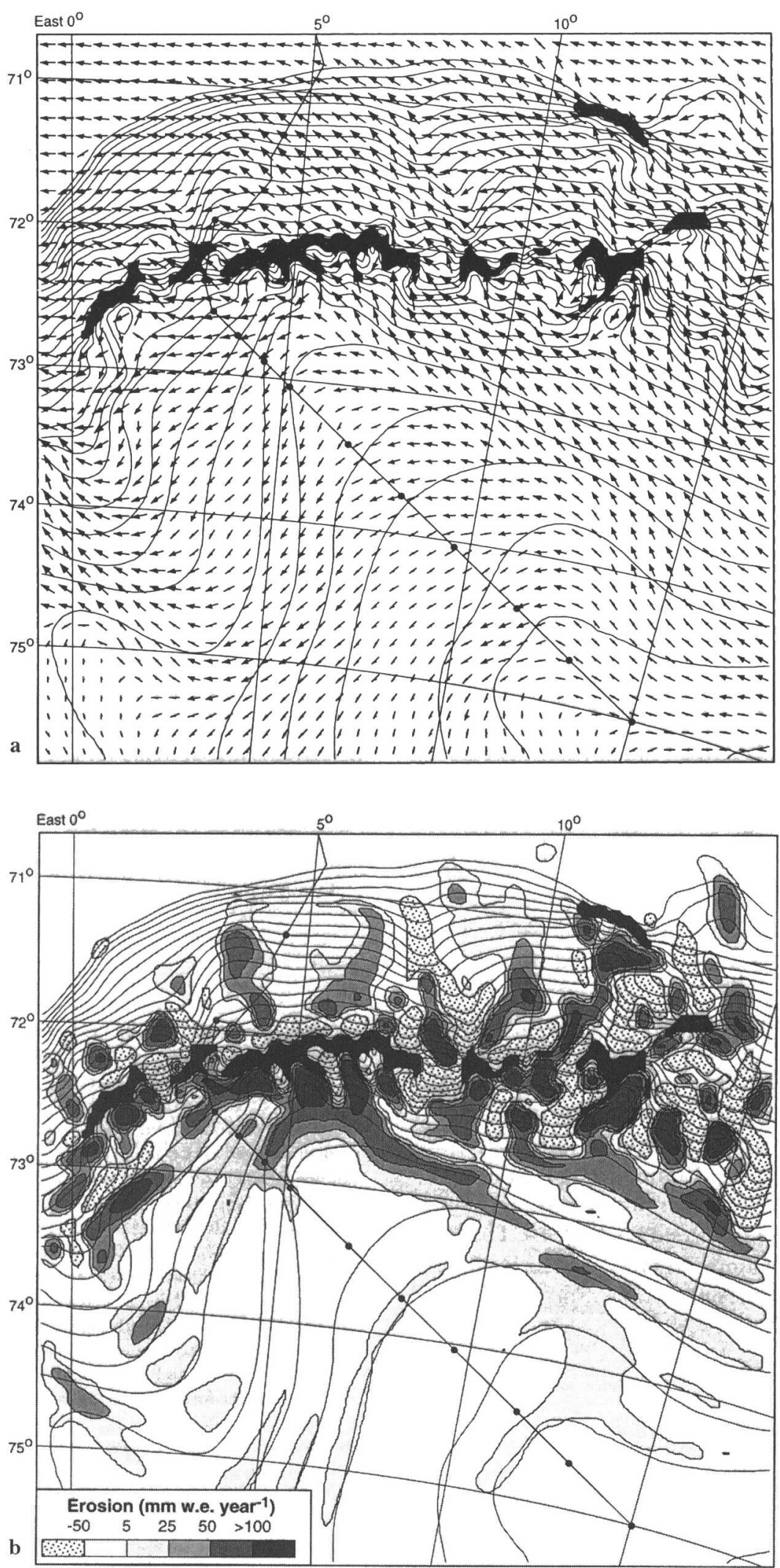

Fig. 8. (a) Calculated climatic wind field, based on expressions by Ball (1960), assuming an easterly geostophic wind of $6 \mathrm{~m} \mathrm{~s}^{-1}$. Solid line indicates traverse route, dots drilling locations. Largest veclor represenls annual mean wind speed of $11 \mathrm{~m} \mathrm{~s}^{-1}$. See text for more details. (b) Annual erosion (mm w.e.) caused by divergence of snowdrift transport, calculated from the wind field presented in (a). Areas where significant deposition occurs ( $>50 \mathrm{~mm}$ w.e.) are stippled. See text for more details.

on the polar plateau at site $\mathrm{L}$ and around sites $\mathbf{F}$ and $\mathbf{G}$. Further north, the observations lack the spatial resolution needed for a comparison with model output, but sitcs $A, S_{15}$ and $S_{20}$ do not appear to be situated in areas with active erosion/deposition. Since we have no additional information on the amount of precipitation, melt and sublimation, a further quantitative treatment of the mass-balance distribution is not justified at this stage. Our results demonstrate, however, that in this part of DML, where strong variations in wind speed occur at relatively high altitudes, the spatial variation of snowdrift transport can have a significant impact on the local mass balance. In areas where most of the wind action 
takes place at lower elevation, sublimation of snow (both from the surface and from suspended snow particles) is also cxpected to play a significant rolc.

\section{SUMMARY AND CONCLUSIONS}

We presented new temperature, firn-density and accumulation data that were obtained along a traverse line in DMI. This part of Antarctica is characterised by high mountains that block the ice flow, resulting in a sudden transition from the polar plateau to the coastal area. The spatial variation of potential temperature, density and accumulation suggests that katabatic winds are active in this region. This is confirmed by deriving proxy wind data from the density profiles of shallow firn cores. A simple katabatic-wind model can explain the variations of accumulation along the traverse line in terms of divergence/convergence of the local transport of drifting snow. Because of the cold, dry climate associated with the high surface elevation south of the mountains, spatial variability of erosion/deposition of snow by the wind has a noticeable impact on the surface mass balance. At these low temperatures, sublimation from the snow surface and of drifting snow particles is likely to be small.

\section{ACKNOWLEDGEMENTS}

This is contribution No. 151 of the Norwcgian Antarctic Research Expedition (NARE) and EPICA publication No. 1. 'The authors wish to thank all mombcrs of the traverse team, participants in NARE 96/97 who assisted at Troll and all the people in the Netherlands, Sweden and Norway who were involved in the preparation of the traversc. T. Braadland, L. Høvik and S. Teigre (Norsk Polarinstitutt) are gratefully acknowledged for preparing the $\beta$ samples and assisting with clectrical conductivity measurements. G. Anker (Norsk Polarinstitutt) is thanked for drafting Figure 1. This work is a contribution to EPICA, a joint European Science Foundation/European Commission scientific programme, funded by the EC under the Environment and Climate Programme (1994-98) contract ENV4-CT95-0074 and by national contributions from Belgium, Denmark, France, Germany, Italy, the Netherlands, Norway, Sweden, Switzerland and the U.K.

\section{REFERENCES}

Ball, F. K. 1960. Wind on the ice slopes of Antarctica. In Antarelic meteorology. Oxford, etc, Pergamon Press, 9-16.

Bintanja, R. and M. R. van den Brocke. 1995. The surface energy balance of Antarctic snow and blue ice. 7. Aptl. Metenrol, 34 4), 902-926.

Bintanja, R., S. Jonsson and W. H. Knap. 1997. The annual cycle of the surface energy balance of Antarctic bluc ice. 7. Geophys. Res., 102 D2), 1867- 1881

Bromwich, D. H. 1989. Satellite analyses of Antarctic katabatic wind behavior. Bull. Am. Meteorol. Soc., 70(7),738-749.

Craven, M. and I. Allison. 1998. Firnification and the effects of wind-packing on Antarctic snow. Ann. Glaciol., 27, 2.39-24.5.

Isaksson, E., W. Karlén, N. Gundestrup, P. Mayewski, S. Whitlow and M. Twickler. 1996. A century of accumulation and temperature changes in Dronning Maud Land, Antarctica. 7. Geophys. Res., 101 (D3), 7085-7094.
Isaksson, E., M. R. van den Broeke, J.-G. Winther, L. Karlöf, J. F. Pinglot and $\mathrm{N}$. Gundestrup. In press. Accumulation and proxy-temperaluro variability in Dronning Maud Land, Antarctica, determined from shallow firn cores. Ann. Glaciol, 29.

Kameda, T., H. Shoji, K. Kawada, O. Watanabe and H. B. Clausen. 1994. An empirical relation between overburden pressure and firn density Ann. Glaciol., 20, 87-94.

King, J. C. and J. Turner. 1997. Antartic meteorology and climatology. Cambridge, Cambridge University Press.

Loewe, F. 1970. The transport of snow on ice sheets by the wind. In Radok, $\mathrm{U}$, ed. Studies on drifting snow: Melbourne, University of Melbourne. Meteorology Department, 21-69. (Meteorology Report 13.)

Lunde, T. 1961. On the snow accumulation in Dronning Maud Land. Nor. Polarinst. Skr. 123.

National Institute of Polar Research (NIPR). 1997. Antartica: east Queen Maud Land/Enderby Land glaciological folio. Tokyo, National Institute of Polar Research.

Pcttré, P., J. F. Pinglot, M. Pourchet and L. Reynaud. 1986. Accumulation distribution in Terre Adélie, Antarctica: effect of meteorological parameters. 7. Glaciol., 32(112, 486-500).

Phillpot, H. R, and J. W. Zillman. 1970. The surface temperature inversion over the Antarctic continent. .7. Geophys. Res., 75 2l, 416l-4169.

Picciotto, E., G. Crozaz and W. de Breuck. 1971. Accumulation on the South Pole-Quecn Maud Land traverse, 1964-1968. In Crary, A. P., ed. Antartic snow and ice siudies II. Washington, DC, American Geophysical Union, $257 \cdot 315$. (Antarctic Research Series 16.)

Pinglot, J. F, and M. Pourchet. 1979. Low-level beta counting with an automatic sample changer. Nucl. Instrum. Methods, 166(3), 483490.

Pourchet, M., F. Pinglot and C. Lorius. 1983. Some meteorological applications of radioactive fallout measurements in Antarctic snows. 7 . Geophys. Res., 88(C10), 6013-6020.

Richardson, C., E. Aarholt, S.-E. Hamran, P. Holmlund and E. Isaksson. 1997. Spatial distribution of snow in wcstern Dronning Maud I and East Antarctica, mapped by a ground-based snow radar. 7. Geophys Res., 102 (B9), 20,343 20,353.

Schlatter, T.W. 1972. The local surface energy balance and subsurface tcmperature regime in Antarctica. 7. Appt. Metenrol., 11(7), 1048-1062.

Schwerdtfeger, W. 1970. 'The climate of the Antarctic. In Orvig, S., ed. Climales of the polar regions. Amsterdam, etc., Elsevier, 253-355.

Schytt, V. 1958. Glaciology II ( $)$. Snow studies at Maudhcim. NonwegianBritish-Swedish Antarctic Expedition, 1949 52. Sci. Results IV.

Seppälä, M. 1992. Stabilization of snow temperatures in Dronning Maud Land, Antarctica, January 1989. Geogr. Ann., 74A (2-3), 227-230.

Streten, N. A. 1990. A review of the climate of Mawson: a representative strong wind site in East Antarctica. Antarct. Sci, 2(1), 79-89.

Takahashi, S., R. Naruse, M. Nakawo and S. Mac. 1988. A bare ice field in cast Qucen Maud Iand, Antarctica, caused by horizontal divergence of drifting snow. Ann. Glaciol., 11, 156160.

Van den Broeke, M. R. 1997. Spatial and temporal variation of sublimation on Antarctica: results of a high-resolution general circulation model. $\mathcal{J}$ Geophys. Res., 102(1)25), 29,765-29,778.

Van den Broeke, M. R. 1998a. The semiannual oscillation and Antarctic climate. Part l: influence on ncar-surfacc tempcratures (1957-1979). Anlaret. Sci. 10(2), 175-183.

Van den Broeke, M. R. 1998b. The semiannual oscillation and Antarctic climate. Part 2: recent changes. Antarct. Sici., 10(2), 184-191.

Van den Broeke, M. and R. Bintanja. 1995a. The interaction of katabatic winds and the formation of blue-ice areas in East Antarctica. 7 . Glaciol, 41 138), 395-407.

Van den Brocke, M. R. and R. Bintanja. 1995b. Summertime atmospherir circulation in the vicinity of a blue ice area in east Queen Maud Land, Antarctica. Boundary-Layer Meteorol., 72 (45), 411-438.

Van den Broeke, M. R., R. S.W. van dr Wal and M. Wild. 1997. Representalion of Antarctic katabatic winds in a high resolution GCM and a note on their climate sensitivity. 7. Climate, 10(12, 3111-3130.

Venteris, E. R. and I. M. Whillans. 1998. Variability of accumulation rate in the catchments of Ice Streams B, C, D and E, Antarctica. Ann. Glaciol., $27,227-230$

Winther, J.-G. and 9 others. 1997. HPICA I)romming Maud Land pre-site survey 1996/97. In Winther, J. G., ed. Report of the Norwegian Antarctic Research Expedition (NARE) 1996/37. Oslo, Norsk Polarinstitutt, 96-117. (Mcidelelser 148. 